\title{
Training of Artifical Intelligence for Detection of Scales of Musical Instruments
}

\author{
W. Porselvi, Sumathi Arjunan, M. M. Shanmuga Priya
}

\begin{abstract}
Learning to play a musical instrument is rewarding in many ways. Through music kids and adults can learn discipline, express creativity and find a healthy way to manage stress. For people who stick to it and get good at it, music might even become a career. But even among those who play just for fun there are very few who regret bringing music into their lives.

Every wannabe musician has to start somewhere, and that somewhere isn't always so easy to figure out. There are so many different instruments out there, each with a strong set of pros and cons.
\end{abstract}

Keywords: - fixed-length music, Softmax, young's modulus.

\section{INTRODUCTION}

Musical instrument detection is one of the familiar tasks in signal processing which has not reached its highest level of detection, given an audio.

Present day regulated learning procedures, for example, profound learning, are known for their capacity to express exceptionally non-straight connections between the information and the yield, given the high profundity and enormous number of parameters [1]. The sound examination frameworks dependent on profound learning have as of late indicated better execution over increasingly conventional AI draws near [2]. For example a music file may contain many instruments played together; our target is to find out the instruments that are played at any instance of time in the given audio. This can also be related to sound event detection [3]..

\section{A. Deep Learning}

Deep learning is a subfield of machine learning where the ability to learn is based on data representations. Contrasted with customary AI techniques, profound learning has solid learning capacity and can utilize datasets for include extraction. Due to its practicability, profound learning turns out to be increasingly more famous for some looks into to do explore works $[4,5]$.

Revised Manuscript Received on December 11, 2019

W. Porselvi , Assistant Professor, Department of Science and Humanities ,Bharath Institution Of Higher Education And Research,TamilNadu, India Email: porselviwilson@gmail.com

Sumathi Arjunan, Assistant Professor, Department of Science and Humanities, Bharath Institution Of Higher Education And Research TamilNadu,India. Email: sumi.renu@gmail.com

M. M. Shanmuga Priya, Assistant Professor, Department of Science and Humanities, Bharath Institution Of Higher Education And Research TamilNadu,IndiaEmail: priyashammu@gmail.com

\section{FEATURE EXTRACTION}

With regards to sound examination, acoustic highlights are extricated from the sound sign to continue further. This is a significant phase of any sound examination framework. The most well-known acoustic highlights used to speak to ghostly substance of sound sign are mel-band energies and mel-recurrence ceptral coefficients (MFCC) [6]. These are favored in light of the fact that it centers around the extents of recurrence segments like the impression of the human sound-related framework.

\section{RESEARCH QUESTION}

Music instrument detection is one of the tasks where there are no comprehensive classification and detection methods available. This proposal focuses on the following question. Can deeplearning be employed to better the detectionof the music instrument in a recording?

\section{PROPOSED METHOD}

The method proposed here will utilize deep learning to learn the parameters of the trained data which includes the temporal aspect of the features. The trained data is then tested on the test data

In the learning stage the training set will be used to train the model. The training examples will consist of the features extracted from the short analysis frames from the music signals. It will also contain the annotations of the training examples. Discrete Fourier Transform (DFT) of each analysis frame will be calculated which gives the magnitude spectrum. From that mel-band energies can be obtained [7]. The temporal aspect of the features can be included by frame stacking. Gradient descent can be used in the iterative process where the network parameters are updated. In order to recognize the music present, the temporal activity is estimated along with the actual class labels for the instrument presence. The first layer of the network takes the features as the input and the output layer will show the class presence probabilities. 


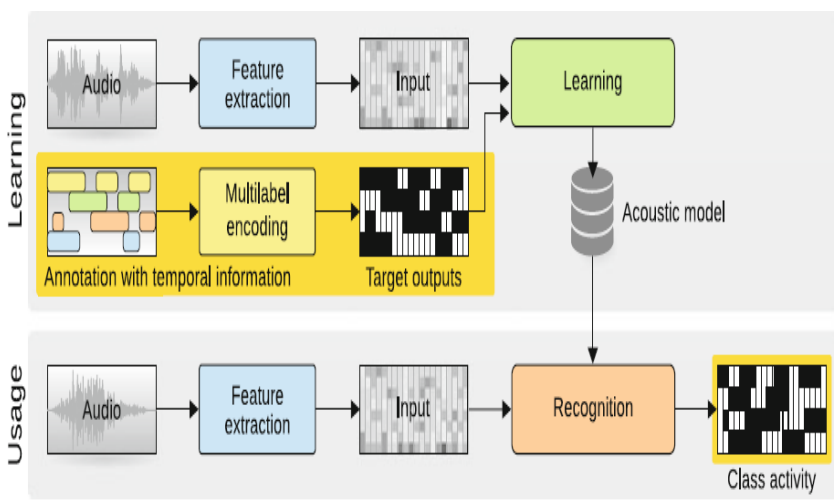

Fig.1. Sound Event Detection [3]

The above basic structure is used in Sound Event Detection [3], which can also be used for the above proposed method to detect the instruments that are being played.

\section{STUDY PLAN}

Table 1: Proposed Study Plan

\begin{tabular}{|c|c|c|c|c|c|c|c|c|c|c|c|c|}
\hline \multirow[t]{2}{*}{ FundamentalElements } & \multicolumn{2}{|c|}{2018} & \multicolumn{3}{|c|}{2019} & \multicolumn{3}{|c|}{2020} & \multicolumn{3}{|c|}{2021} & \multirow{2}{*}{2022} \\
\hline & 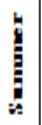 & 5 & 量 & 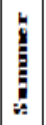 & $\frac{5}{b}$ & 宸 & 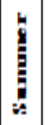 & 5 & 湿 & 8 & 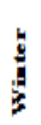 & \\
\hline \multicolumn{13}{|l|}{ Problem definition } \\
\hline \multicolumn{13}{|l|}{ Theoretical Studies } \\
\hline \multicolumn{13}{|l|}{ Audio data collaction } \\
\hline \multicolumn{13}{|l|}{ Psper 1} \\
\hline \multicolumn{13}{|l|}{ Audio data annotation } \\
\hline \multicolumn{13}{|l|}{ Initial system design } \\
\hline \multicolumn{13}{|l|}{ * Short-Term Scientific Mission - 1} \\
\hline \multicolumn{13}{|l|}{ Paper 2} \\
\hline \multicolumn{13}{|l|}{ Audio procassing parts } \\
\hline \multicolumn{13}{|l|}{ Paper 3} \\
\hline \multicolumn{13}{|l|}{ * Shont-Term Scientific Mission - 2} \\
\hline \multicolumn{13}{|l|}{ Machine leaming parts } \\
\hline \multicolumn{13}{|l|}{ * Shont-Term Scientific Mission - 3} \\
\hline \multicolumn{13}{|l|}{ Paper 4} \\
\hline \multicolumn{13}{|l|}{ System integration } \\
\hline \multicolumn{13}{|l|}{ System evaluation } \\
\hline \multicolumn{13}{|l|}{ Paper 5} \\
\hline Thasis writing \& Defense & & & & & & & & & & & & \\
\hline
\end{tabular}

* Time Period may vary according to the Alto University regulations for taking the theoretical courses

** Time Period may vary according to the need of the research to be carried (Short-Term Scientific Missions were taken in account from the advertisement of the position) [Note: The above study plan is subjected to change according the instructions of the supervisor depending upon the requirements of the project]

\section{CONCLUSION}

Deep Learning has proven its ability to outperform the regular machine learning algorithms. The approach that has been proposed has also shown a commendable performance in sound event detection of environmental sounds. This could possibly be a great challenge to apply it for the musical instrument detection in a given audio, which will give a higher probability of presence of instruments.

\section{REFERENCES}

1. Vasanthi, S. \& Rabiyathul Basariya, S. 2019, "Influence of value analysis and cross training in industry", International Journal of Engineering and Advanced Technology, vol. 8, no. 6, pp. 1810-1811.

2. Velvizhi, R., Sri Gowtham, S. \& Jeya Priya, D. 2019, "Examination of early feedbacks for effective product retailing on E-commerce websites", International Journal of Engineering and Advanced Technology, vol. 8, no. 6 Special Issue 2, pp. 703-706.

3. Anuradha, C., Pothumani, S. \& Kavitha, R. 2019, "A novel method towards E-commerce", International Journal of Engineering and Advanced Technology, vol. 8, no. 6 Special Issue 2, pp. 535-538.

4. Thomas, J. \& Rabiyathul Basariya, S. 2019, "A study on the issues of financial ratio analysis", Indian Journal of Public Health Research and Development, vol. 10, no. 3, pp. 1079-1081.

5. Ramachandran, S. \& Rabiyathul Basariya, S. 2019, "Online marketing study on customer satisfaction and relationship", Indian Journal of Public Health Research and Development, vol. 10, no. 3, pp. 1072-1078.

6. Priya, R., Vinothini, G. \& Cor Jesu, C.D. 2019, "The mentor-protégé relationship for professional growth", Journal of Advanced Research in Dynamical and Control Systems, vol. 11, no. 9 Special Issue, pp. 1110-1119.

7. Jannifer Rani, N., Bina Pani, S. \& Nimisha, N.S. 2019, "A study on money back polices available in LIC", Journal of Advanced Research in Dynamical and Control Systems, vol. 11, no. 9 Special Issue, pp. 833-839.

8. Saillaja, V., Jhansi Rani, K. \& Catherine, R. 2019, "Global marketing management planning and organization", Journal of Advanced Research in Dynamical and Control Systems, vol. 11, no. 9 Special Issue, pp. 489-493.

9. Saillaja, V., Jhansi Rani, K. \& Catherine, R. 2019, "The new phase of marketing information system", Journal of Advanced Research in Dynamical and Control Systems, vol. 11, no. 9 Special Issue, pp. $482-488$

10. Thoufiqulla \& Raju, D.V. 2019, "Perception of indian investor towards investment in mutual funds with special reference to mip funds", Journa of Advanced Research in Dynamical and Control Systems, vol. 11, no. 5, pp. 177-183.

11. Jasmine, K.R.M. \& Basariya, S.R. 2018, "A study on the customers benefits on mutual funds", International Journal of Civil Engineering and Technology, vol. 9, no. 4, pp. 45-48.

12. Vasanthi, S. \& Basariya, S.R. 2019, "Pros and cons of on the job training versus off the job training", International Journal of Scientific and Technology Research, vol. 8, no. 10, pp. 671-674.

13. Pavithra, J. \& Ganesan, M. 2016, "A study on awareness and impact of micro-financial schemes", International Journal of Applied Business and Economic Research, vol. 14, no. 8, pp. 5449-5460.

14. Pavithra, J., Dilli Babu, P. \& Ambuli, T.V. 2014, "A study on budgetary control at Maruti Service Masters, Chennai", International Journal of Applied Business and Economic Research, vol. 12, no. 2, pp. 151-161.

15. Gunaraja, T.M. \& Venkatrama Raju, D. 2018, "Determining factors of organisational climate with reference to leadership styles", International Journal of Mechanical Engineering and Technology, vol. 9, no. 9, pp. 1327-1332.

16. Gunaraja, T.M. \& Venkatrama Raju, D. 2018, "The role of job satisfaction and training of employees in determining organisational climate of a selected industry", International Journal of Civil Engineering and Technology, vol. 9, no. 8, pp. 1266-1269.

17. Aarathy, T.S. \& Raju, D.V. 2018, "Performance appraisal and its effects on employees with respect to it sector in Chennai city", International Journal of Civil Engineering and Technology, vol. 9, no. 6, pp 1535-1538. 
18. Aarathy, T.S. \& Raju, D.V. 2018, "Employee perception towards performance appraisal system in IT sector", International Journal of Mechanical Engineering and Technology, vol. 9, no. 5, pp. 131-135.

19. Porselvi, W., Jublee, D. \& Sivanesan, G. 2018, "A study on factors influencing adoption of technology and innovation in banking industry, tamilnadu, India", International Journal of Mechanical Engineering and Technology, vol. 9, no. 5, pp. 789-800.

20. Akessa, G.M. and Dhufera, A.G., 2015. Factors That Influences Students Academic Performance: A Case of Rift Valley University, Jimma, Ethiopia. Journal of Education and Practice, 6(22), pp.55-63.

21. Miller, G. and Shih, C.C., 1999. A faculty assessment of the academic rigor of on-and off-campus courses in agriculture. Journal of Agricultural Education, 40, pp.57-65.

22. Tsinidou, M., Gerogiannis, V. and Fitsilis, P., 2010. Evaluation of the factors that determine quality in higher education: an empirical study. Quality Assurance in education, 18(3), pp.227-244.

23. Farooq, M.S., Chaudhry, A.H., Shafiq, M. and Berhanu, G., 2011. Factors affecting students' quality of academic performance: a case of secondary school level. Journal of quality and technology management, 7(2), pp.1-14.

24. Fitsilis, P., Gerogiannis, V. and Anthopoulos, L., 2014. Ontologies for software project management: a review. Journal of Software Engineering and Applications, 7(13), p.1096.

25. Adams, J.D. and Jaffe, A.B., 1996. Bounding the effects of R\&D: an investigation using matched establishment-firm data(No. w5544). National bureau of economic research.

\section{AUTHORS PROFILE}

W. Porselvi Assistant Professor, Department of Science and Humanities,Bharath Institution Of Higher Education And Research,TamilNadu, India

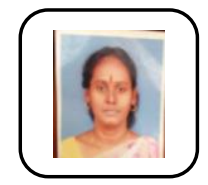

Sumathi Arjunan Assistant Professor, Department of Science and Humanities,Bharath Institution Of Higher Education And Research,TamilNadu, India.

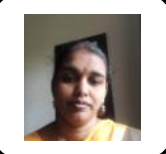

M. M. Shanmuga Priya Assistant Professor, Department of Science and Humanities,Bharath Institution Of Higher Education And Research,TamilNadu, 